\title{
FAIRY TALE STORIES AS THE CULTURAL GROWER OF LITERACY READING FOR PRIMARY SCHOOL STUDENTS
}

\section{Siti Mustakimah, Maulida Ajeng Priyatnomo, Muhamad Chamdani}

Universitas Sebelas Maret

sitimustakimah55@gmail.com

\section{Article History}

accepted 30/09/2018

approved 12/10/2018

published 30/10/2018

\section{Keywords}

literacy culture, fairy tale story, primary school students

\begin{abstract}
The children's ability on literacy is essential for their ability development and academical achievement. The purposes of this article are 1) describing fairy tale stories, 2) describing the culture of literacy reading, 3) describing fairy to grower of literacy for primary school students. The research method used was literature study. The data was obtained by doing research study towards some literatures, books, reports and notes included the research problems. The results of this research explains about 1) the description of fairy tale stories, 2) the description of the culture of literacy reading, 3)the description of the usage of fairy tale stories as the literacy culture for children in primary school. The conclusion of this research is that fairy tale is fictional, imaginative, morale and understandable story so that it could be used as an alternative in growing the literacy culture particularly literacy reading for primary school students.
\end{abstract}

Social, Humanities, and Education Studies (SHEs): Conference Series https://jurnal.uns.ac.id/shes
p-ISSN 2620-9284 e-ISSN 2620-9292 


\section{PENDAHULUAN}

Usia dini merupakan periode yang sangat penting dan mendasar bagi perkembangan dan pertumbuhan anak. Pada masa ini disebut masa keemasan anak, karena pada usia dini anak mulai peka terhadap berbagai rangsang yang ada di sekitarnya. Pada anak usia Sekolah Dasar adalah saat yang sangat baik untuk mengembangkan kemampuan kognotif (pengetahuan) dan keterampilan siswa.

Menurut Piaget (dalam Yusuf, 2014: 6) tahapan perkembangan kognitif anak terbagi menjadi 4, yaitu:

1) Tahap Sensorimotor (usia 0-2 tahun). Pada tahap ini pengetahuan anak diperoleh dari interkasi fisik antara orang dengan orang/benda. Interaksi ini masih terbatas pada gerakan refleks sederhana, seperti mengisap atau menggenggam.

2) Tahap Praoperasional (2-6 tahun). Tahap ini anak sudah mulai menggunakan simbol untuk lingkungan sekitar secara kognitif. Simbol-simbol ini meliputi, katakata dan bilangan yang digunakan untuk menggantikan objek, peristiwa, dan kegiatan.

3) Tahap Operasional Konkret (6-11 tahun). Anak sudah membentuk operasi konkret berdasarkan pengetahuan yang mereka miliki, seperti menambah, mengurangi, dan mengubah. Dalam tahap ini anak sudah dapat memecahkan masalahnya sendiri secara logis.

4) Tahap Operasional Formal (11 tahun - dewasa). Anak sudah dapat berhubungan dengan peristiwa-peristiwa abstrak. Mereka sudah dapat berfikir secara abstrak dan memecahkan masalah melalui semua pengujian yang ada.

Menurut Hasan (2008) Kemampuan membaca dan menulis saat prasekolah dan Sekolah Dasar sangat penting untuk menunjang kesuksesan di bidang akademis anak. Untuk mengembangkan kemampuan kognitif siswa maka kegiatan membaca sangat penting. Membaca merupakan faktor yang sangat menentukan dana proses pendidikan anak usia sekolah dasar. Anak yang sudah belajar membaca sejak usia dini akan tumbuh menjadi pembaca aktif, sementara anak yang tidak belajar sejak usia dini akan mengalami hambatan dalam membaca ( Lonigan, 2006).

Fenomena yang terjadi saat ini adalah adanya tuntutan pendidikan kepada anak usia sekolah dasar agar bisa membaca dan menulis sebagai syarat masuk sekolah. Dengan adanya persyaratan tersebut maka banyak orang tua yang mengajarkan membaca dan menulis kepada anaknya dengan berbagai metode yang dianggap cukup mudah. Membaca dongeng merupakan salah satu cara yang mudah dan menarik untuk meningkatkan kemampuan literasi kepada anak usia Sekolah Dasar. Cerita dongeng memiliki daya tarik tersendiri yaitu dengan keunikan ceritanya dan tokoh-tokoh yang berperan dalam cerita tersebut.

Pengertian literasi menurut Baynham (1995:9) adalah integrasi keterampilan menyimak, membaca, menulis, berbicara, dan berpikir kritis. Manusia dapat berkomunikasi dengan baik karena memiliki literasi yang baik pula. Literasi mencakup yang tercakup lisan dan tulisan. Sekarang ini anak orang tua yang membiarkan anaknya memperoleh informasi dari perangkat teknologi, sehingga menurunkan budaya menulis dan membaca anak.

Selain keluarga, lingkungan luar seperti sekolah juga sangat berpengaruh terhadap pembentukan pendidikan dan karakter anak. Untuk menciptakan budaya literasi anak usia sekolah dasar sebaiknya di lingkungan sekolah difasilitasi perlengkapan literasi seperti tersedianya buku cerita. Buku cerita yang menarik minat baca anak asalah satunya adaah cerita dongeng, karena dalam sebuah cerita dongeng terdapat tokoh-tokoh yang sangat unik, dan jalan cerita yang mudah dipahami oleh anak. namun, pada kenyatanya saat ini di Sekolah Dasar sudah tidak ada pelajaran tentang cerita dongeng sehingga sudah jarang sekali buku-buku cerita dongeng yang tersedia. Dari pihak gurupun tidak pernah memberikan cerita dongeng. Hal ini menyebabkan anak-anak usia sekolah dasar sekarang tidak mengenal dongeng. 


\section{METODE}

Metode yang digunakan dalam penelitian ini menggunakan metode studi kepustakaan. Menurut Nazir (2003) studi kepustakaan merupakan sebuah teknik untuk mengumpulkan data dengan cara melakukan studi penelaahan literatur, buku, laporan, dan catatan yang berhubungan dengan masalah yang akan dipecahkan. Dalam hal ini peneliti melakukan kajian yang berkaitan dengan teori yang mendukung topik penelitian, mengumpulkan informasi, dari kepustakaan yang berhubungan.

\section{HASIL DAN PEMBAHASAN}

Pada bagian ini akan dibahas 3 pokok bahasan, yaitu : 1) Deskripsi cerita dongeng, 2) Deskripsi budaya literasi membaca, 3) Cerita dongeng sebagai penumbuh budaya literasi membaca bagi anak Sekolah Dasar.

\section{Cerita dongeng}

\section{a. Pengertian Cerita Dongeng}

Dongeng adalah cerita yang bersifat fiksi dan menghibur untuk yang menjadi audience dan manfaatnya dari dongeng sendiri ada unsur-unsur petuahnya. Danandjaya (2007) menyatakan, dongeng ialah prosa rakyat yang dianggap tidak pernah terjadi, dan ceritakan terutama untuk hiburan, sekalipun tidak sedikit yang melukiskan kebenaran yang berisi moral bahkan sindirian. Dongeng biasanya memiliki kalimat pembukaan dan penutupan. Dongeng jawa biasanya diawali dengan kalimat "Anuju sawijining dina dan diakhiri A dan B urip rukun bebarengan kaya mini lan mintuna...(A dan $B$ hidup bersama dengan rukun bagaikan ketam belangkas jantan dan ketam belangkas betina).

\section{b. Macam-macam cerita dongeng}

Menurut Yudha (2007) dongeng dapat dibagi menjadi 4 jenis, yaitu :

1) Dongeng tradisional, ialah dongeng yang berkaitan dengan cerita rakyat yang biasanya turun-temurun. Dongeng tradisional juga bermanfaat menghibur kesedihan dan menanamkan semangat kepahlawanan. Contoh : Malinkundang, Calon Arang, Sangkuriang, dan lain sebagainya.

2) Dongeng Futuristik (modern) atau fantastik; dongeng yang bercerita tentang sesuatu yang fantastik dan futuristik, seperti star tret, bumi abad $\mathrm{XV}$, dan lain sebagainya.

3) Dongeng pendidikan; dongeng yang diciptakan dengan misi pendidikan bagi dunia anak, misalnya menggugah sikap hormat kepada orang tua.

4) Fabel; dongeng tentang kehidupan binatang yang digambarkan bisa bicara seperti manusia. Cerita-cerita sangat luwes digunakan untuk menyindir perilaku manusia tanpa membuat manusia tersinggung. Misalnya dongeng si Kancil.

5) Dongeng sejarah; dongeng yang berkaitan dengan peristiwa sejarah, seperti kisah-kisah nabi, sejarah perjuangan bangsa, dan lain sebagainya.

6) Dongeng terapi; dongeng yang bisa membuat rileks sarat-sarat otak dan membuat tenang hati mereka.

\section{Pengertian Budaya Literasi Membaca}

Budaya menurut Menurut Ayatrohaedi (1986) kebudayaan sangatlah berhubungan dengan masyarakat. Kalimat lain untuk pendapat itu adalah CulturalDeterminism. Kebudayaan merupakan cakupan semua yang kompleks dan didalamnya terkandung pengetahuan, kepercayaan, kesenian, moral, hukum, adat 
istiadat, dan kemampuan-kemampuan lain yang didapat seseorang sebagai anggota masyarakat.

Kebudayaan bisa diterjemahkan semua hal yang berkaitan dengan akal (Koentjaraningrat, 2009:146). Menurut Taylor (Harsojo, 1984:92) kebudayaan ialah keseluruhan kompleks dan didalam mengandung ilmu pengetahuan, kepercayaan, kesenian, moral, hukum, adat istiadat,dan kemampuan yang lain serta kebiasaan yang diadaptasi oleh manusia sebagai anggota masyarakat".

Menurut D"Andrade (Supardan, 2008:201) pengertian kebudayaan condong kepada sekumpulan pengetahuan yang secara sosial diturunkan dari satu generasi ke generasi dibawahnya yang mencolok dengan makna keseharian yang hanya merujuk pada warisan sosial tertentu yakni tradisi sopan santun dan kesenian.

Secara sederhana, literasi mampu dikatakan sebuah kemampuan membaca dan menulis. Namun, pada era sekarang, literasi mempunyai arti yang mencangkup lebih luas, sehingga mengandung beragam arti. Ada macammacamnya yaitu literasi komputer, literasi media, literasi teknologi, literasi ekonomi, literasi informasi, bahkan ada literasi moral. Literasi pada saat ini mampu disimpulkan melekteknologi, melek informasi, berpikir kritis, peka terhadap lingkungan sekitar, dan memungkinkan untuk melek terhadap perkembangan politik (Permatasari, $2015: 148$ )

Kesimpulan dari uraian di atas bahwa budaya literasi membaca adalah suatu pengetahuan dan dan aturan-aturan yang diadaptasi oleh suatu masyarakat tertentu menjadi sebuah kebiasaan terutama dalam hal membaca di suatu lingkup tertentu.

3. Cerita dongeng sebagai penumbuh budaya literasi bagi anak sekolah dasar

Perlu kita ketahui bahwa untuk menciptakan seseorang mampu melek literasi membutuhkan proses panjang dan sarana yang kondusif. Proses ini dimulai dari faktor-faktor kecil, lingkungan keluarga, lantas didukung lingkungan pergaulan, lingkungan pekerjaan maupun lingkungan sekolah. Budaya literasi berkaitan dengan pola pembelajaran di sekolah dan ketersediaan bahan bacaan di perpustakaan (Permatasari, $2015:$ 148).

Menurut Akbar (2017 : 10) Budaya literasi wajib dikembangkan di sekolah dasar agar para siswa mampu membiasakan diri mencari informasi-informasi yang ada kaitannya dengan pembelajaran dan bagi dirinnya sendiri. Dari pendapat di atas dapat disimpulkan bahan sekolah juga berperan adanya pengembangan literasi membaca bagi anak-anak terutama di sekolah dasar.

Untuk meningkatkan terbentuknya budaya literasi terutama membaca menurut Permatasari (2015 : 153) salah satunya dengan program-program lanjutan untuk mengenalkan buku dan mendorong minat baca buku ke sekolah dan masyarakat umum. Fokuskan kepada sesuatu yang mampu menarik dan universal untuk memikat kau muda untuk membaca.Menurut Yudha (2007) Dongeng menawarkan adanya intrepetasi dengan mengenalkan kehidupan di luar diri anak. Anak dikenalkan pada berbagai cara pola, pendekatan tingkah laku, sehingga mereka mendapat ilmu baru yaitu tentang kognitif, afektif, penghayatan dan imajinasi untuk bekal berhadapan dengan masa depan maupun masa lalu. Dari uraian di atas mampu disimpulkan bahwa salah satu buku yang menarik ataupun bacaan yang menarik dan cocok bagi anak sekolah dasar adalah cerita dongeng. Cerita dongeng mampu membuat anak berkembang imajinasinya, kognitif, afektif, maupun pengahayatannya. Hal ini apabila sekolah mampu memberikan fasilitas buku cerita dongeng yang menarik bagi anak sekolah dasar, 
maka budaya literasi membaca akan ada pertumbuhan sedikit demi sedikit.Seperti pendapat Patimah (2015) Cara membuat siswa tertarik terlebih dahulu adalah dengan cara guru membiasakan mendongeng atau bercerita secara bertahap. Rasa penasaran dari siswa akan menuntun siswa untuk mencari sendiri cerita itu. Hal ini hanya bisa dilakukan tentu saja dengan siswa sendiri membaca cerita tersebut. Adanya rasa penasaran siswa inilah yang bisa dimanfaatkan oleh guru untuk mengarahkan siswa membaca. Kegiatan ini secara jangka panjang akan menumbuhkan budaya membaca anak serta budaya literasi siswa. Maka dari itu, sekolah juga berperan sebagai tumbuh kembang budaya literasi membaca bagi anak sekolah dasar.

\section{SIMPULAN}

Dongeng adalah cerita yang bersifat fiksi dan menghibur untuk yang menjadi audience dan manfaatnya dari dongeng sendiri ada unsur-unsur petuahnya. Karena sifatnya yang imajinatif dan ringan untuk dipahami, dongeng bisa menjadi salah satu alternatif untuk menumbuhkan budaya literasi membaca anak sekolah dasar. Dengan adanya ketertarikan siswa tentang cerita dongeng, maka siswa akan berusaha mencari tahu sendiri bagaimana kisah itu tertulis. Dengan siswa mencari tahu, mau tidak mau siswa harus membaca sendiri bagaimana kisah dongeng yang diinginkan. Dengan seperti itu mampu menumbuhkan sedikit demi sedikit budaya literasi membaca bagi anak sekolah dasar.

\section{DAFTAR PUSTAKA}

Akbar, A. (2017). Membudayakan Literasi Dengan Program 6M Di Sekolah Dasar. JPSD Vol. 3 No. 1 ISSN 2540-9093

Ayatrohaedi. E. (1986). Kepribadian Budaya Bangsa (Local Genius). Jakarta : Pustaka Jaya.

Baynham, M. (1995) Literacy Practices: Investigating Literacy in Social Contexts. London: Longman.

D' Supardan. (2008). Pengantar IImu Sosial Sebuah Kajian Pendekatan Structural. Jakarta: Bumi Aksara.

Danandjaya. 2007. Foklor Indonesia. Jakarta: PT. Pusaka Utama Grafiti.

Harsojo. (1984). Pengantar Antropologi. Bandung: Binacipta.

Hasan, M. (2008). Pendidikan Anak Usia Dini. Jogjakarta. Diva Press.

Koentjaraningrat. (2009). Pengantar Ilmu Antropologi. Jakarta : PT. Rineka Cipta

Lonigan, C. J. (2006). Development, Assesment, and Promotion of Preliteracy Skills. Early Education and Development, 17 (1), 91-114.

Nazir, M. (2003). Metode Penelitian. Jakarta: Ghalia Indonesia.

Patimah, P. 2015. Efektifitas Metode Pembelajaran Dongeng Dalam Meningkatkan Kemampuan Literasi Anak Pada Jenjang Usia Sekolah Dasar. Al Ibtida : Jurnal Pendidikan Guru MI, 2(2)

Permatasari, A. (2015). Membangun Kualitas Bangsa dengan Budaya Literasi. Diunduh dari repository.unib.ac.id/11120/ pada tanggal 20 Oktober 2018.

Yudha, Andi. 2007. Cara Pintar Medongeng. Bandung : Mizan Media Utama

Yusuf, S. (2014). Psikologi Perkembangan Anak dan Remaja. Bandung: PT. Remaja Rosdakarya. 